\title{
Some Events About the History of Ancient Khorezm Rural Elements of Defense
}

\author{
Muzaffar Kurbanov, Urgench State University Republic of Uzbekistan, Muzaffar.1983@inbox.ru
}

\begin{abstract}
The article examines, on the basis of archaeological sources, the history of the defensive elements of the rural communities of the Khorezm oasis.
\end{abstract}

Keywords: Odey-Depe, Kushkala, Butentau-1.3, Kangakal'a-1.2, Khumbuztepa, Burlikala, Ayazkala-1.3, Jigerbend, Yonboshkala, Bolshaya and Malaya Kirkkizkala, Koy-krylgan-kal'a, Angakashal'a, Angakal'a Olmaotishgan-1,2, Tuprakkala (Shavat), Tashkala-2, Tashkhirmontepa, Kunarlikala, Kaparas, Dingilje, Kizilkala, Sandikli.

Received: 02.12.2020

Accepted: 13.01 .2021

Published: 05.02.2021

\section{Introduction}

Based on the publications of the Khorezm archeological and ethnographic expedition led by SP Tolstov and the results of archeological researches of Karakalpak archeologists on the borders of the right and left banks of the Amudarya in the historical period and its various stages in the settlements of the Iron and Antiquity period. -places serve as a theoretical source in covering the history of defense elements. The geographical role of rural community associations in housing construction and its development plays an important role. Depending on the geographical location, it can be divided into the following types:

The first group may involve natural elevations. They are divided into the following types depending on their function and defensive ability:

The first type. Mountain ridge (Burliqal'a, Ayozqal'a-1);

The second type. Natural elevation in the plain (Butentou-1,3, Qangqala-1);

The third type. The height connected to the foot of the river (Odoytepa, Qushqala, Khumbuztepa, Jigarband).

The second group includes settlements built on the plains: Yonboshqala, Ayozqala-3, Katta Kirqqizqala, Kichik Kirqqizqala, Koyqirilganqala, Odamliqala, Jildiqqala, Anqaqala, Qorgoshinkal'a, Uyqalqaa, 1,29qaqalqa, Qumbosqalqa Yangiariq), Tpaqrqala (Khiva), Toshqala-2, Akchungul, Tashkhirmontepa, Konarliqala, Quyisoyqal'a, Kaparas, Qanqaqala-2, Boldimsoz.

In the IX-VIII centuries BC, the population of northern Bactria migrated to the left bank of the middle part of the Amu Darya, built a settlement on the basis of knowledge of clay architecture, and its development continued in the later historical period on the vast plains to Mount Shorakhan and Sultan Uvays. Residents of the Khorezm oasis used well-developed planning knowledge in housing construction.

The planning of the villages raised by the population of the IX-U centuries BC was varied. Circle (Odoytepa), corner (Qanqqaqal'a, Kushkal'a, Butentou, Ding'ilja)

IV-I century BC. Tugriburchak (Yonboshqala, Almaotishgan-2, Qorgoshinqala, Ayozqala-1,3, Boldimsoz, Kaparas, Koziqrilganqala). Square plan (Anqaqala, Tiroqqal'a (Khiva), Toshqal'a-2, Katta Qirqqizqal'a, Kaparas, Jildikkal'a, Qizilqal'a). Fortresses with a circular plan (Little Kyrgyz, Almaty-1). In a circle (Koyqrilganqala, Tiroqqalqa (Shovot)).

In the second half of the IX century BC - 1V centuries AD Kuyi Amudarya. Sarikamishbui cultural and economic centers, the location of the villages, their size, the appearance of the defense complex allowed to divide them into the following types:

Type 1 Interior Structure Features:

A) Excluding rooms: Ayozkal'a-1, Katta Kirkkizkal'a, Sandikli, Anqaqal'a, Tiroqqal'a (Shovot), Anqaqal'a, Tiroqqal'a (Khiva).

B) The inner part consists of streets, mahallas and a temple: Kaparas, Qangqaqal'a).

The function of housing can be divided into the following types:

Type 1. Military fortresses (Anqaqala, Tiroqqal'a (Khiva), Burliqal'a, Ayozqal'a-1)

Type 2. Secular and ideological centers (Koykirlanganqala, Tashkhirmontepa, Toshqala-2, Tiroqqala (Shovot))

Rural communities can be divided into the following types depending on the size of the settlement: Type 1. 0.5-2 ha. Kushkala - 0.5 ha, Dingilja - 0.5 ha, Odaytepa - 0.5 ha, Toshqala - 2 - 0.5 ha, Anqaqala - 0.6 ha, Almaotishgan - 1-2 ha, Boldimsoz - 1 ha, Korgoshinkala -1.9 ha, Qizilqala-1,5 ha, 
Type 2. 3-5 ga. Akchakelin - 2.5 hectares, Dovdanqala - 2.89 hectares, Almaty - 2-3.5 hectares, Yonboshkala - 3.5 hectares, Shohsanam - 4.8 hectares, Yarbekirkala - 4.8 hectares,

The defensive elements of the rural settlements were represented by a brick wall, a tower, a shinak, an arch, and a front gate.

Building materials. At the end of the IX-BC-VIII centuries BC, our ancestors used straw, reeds and wood in the construction of villages, along with rectangles made of clay, square bricks, sand and stones. Historical records indicate that the use of square bricks in clay architecture is explained by Sumerian activity. [1] From the beginning of the 5th century BC, square bricks $(45 \times 45 \times 14 \mathrm{~cm}, 42 \times 42 \times 12 \mathrm{~cm}$, $40 \times 40 \times 10 \mathrm{~cm}$ ) were used in the construction of Khorezm villages in clay architecture. In the III-II centuries $\mathrm{BC}$ in the construction of villages were used square bricks of reduced size $(38 \times 38 \times 12 \mathrm{~cm}$, $36 \times 36 \times 10 \mathrm{~cm}$ ). During the first and third centuries AD, square bricks were used in rural settlements. $(34 \times 34 \times 12 \mathrm{~cm}, 33 \times 33 \times 10 \mathrm{~cm})$. In the IV-IV centuries BC, the Khorezm oasis was dominated by square bricks with precise dimensions in the construction of rural settlements. The square bricks depict different symbols (circle, semicircle, crescent, parallel lines, two or three dots, different letters). [2] However, stone and sand were used as materials in the construction. Stone was used in the corridors of the monuments Butentou-1, Toshkala-2. The bricks are combined with $0.3-0.20 \mathrm{~cm}$ of clay. Square bricks were the leading material in the construction of public buildings in the interior of the village.

The wall. The wall plays a special role in the formation and development of rural settlements. The location of the wall population defined the territorial geographical boundary. Rural settlements had external and internal walls. Exterior and interior walls are functionally and architecturally separable. The outer wall consists of cotton, brick, cotton-block, tower, pilasters, shingles and circular holes. The inner walls are devoid of defensive elements. The base of the wall is made of straw, the upper part of which is laid at right angles, square bricks.

In the plains of irrigated agricultural oases, the foundation of the villages was sand.

The thickness of the defensive wall of the dwellings: Koykrilganqala-5 m, Yonboshqal'a-5 m, Jildiqqala-8 m, [3] Ayozqal'a-1-6 m, Ayozqal'a-3-8 m, Kaparas-7 m, Qorgoshinkala-7 m, Katta Kirqqizqala-8 m, Tiroqqal'a (Khiva) -7 m, Tiroqqal'a (Yangiariq) -6 m, Almaotishgan-2-5 m, Jigarband-7 m.

Proteichism (Additional wall). In the IV-I centuries BC BC, the walls and towers of rural settlements on the right and left banks of the Amudarya were covered with a straw wall on the outside. Koykrilganqala, which belongs to the ancient period, The outer walls of such fortresses as Tiroqqal'a (Khiva), Tiroqqal'a (Shovot), Burliqal'a, Katta Qirqqizqal'a, Qorgoshinkala, Shoxsanam, Kaparas, Anqaq'ala are covered with additional walls. As a result of the addition of an additional wall to the walls from the outside and inside, the width of their lower part increased, and their height was adjusted. The additional wall was the second line of defense after the trench. The main function of the additional wall covering the outer wall was to keep the enemy military equipment away.

Researchers dealing with the history of Khorezm defense structures record proteichism as an additional wall or barrier wall attached to the outside of the wall. [4]

Corridor. This style was practiced in a historical period with defensive walls and towers. The style served to separate the outer and inner wall at a precise distance from each other. The size of the middle of the walls is $2-2.5 \mathrm{~m}$. The size of the corridors between the outer and inner walls of rural settlements: Small Kyrgyz-2 m, Kurgoshinkala - 2.3 m, Yonboshkala - 2.8 m, Tuprakkala (Yangiarik) - 1.82 m, Ayozkala - 1-2, 5 m, Ayozqal'a-3-2,70 m, Tiroqqal'a (Khiva) -1,65-1,70 m, Katta Qirqizqiz'ala-2,8-3 m, Jigarband-2 m, Almaotishgan-2-2 m.

Burj. In the Iron Age and antiquity, the constellations had a special place in the defense of rural settlements. It is expedient to divide the towers into the following types in terms of architectural structure: a). Semicircle and circle; b) .Rectangle; v). Square; g). "Swallow's tail"; d). Pillars in the form of pilasters. The towers were built in a historical period with a cotton wall. From the 5th century BC to the 1 st century $\mathrm{AD}$, the outer walls of rural settlements consisted of defensive elements in the form of circles, semicircles, rectangles, and square towers. Those who have a right-angled constellation: Korgoshinkala, Tuprakqala (Khiva), Shohsanam, Anqaqala. Circular and semi-circular tower villages: Ayozqala-1,3, Koyqrilganqala, Pilqala, Toshqala-2, Jigarband, Tiroqqala (Shovot), Almaotishgan-2, Pilqala, Kaparas.

"Swallow-tailed" towers: Ayozqala-1,3, Pilqala, Qalliqir-2. Square-type tower villages: Anqaqala corner, Tiroqqal'a (Khiva), Koyqrilganqala wall top. The size of the defensive area between the towers of the defensive wall is as follows: Tpaqrqala (Shovot) -22m, Taraqqalqa (Khiva) -22-38m, Almaotishgan-227m, Ayozqal'a-3-22-22,5m, Katta Kyrkqizkal-26m, Kaparas-27m Qizilqala-30m, Tiroqqal'a (Yangiarik) 22-24m, Qorgoshinkala-6-37m, Almaotishgan-1-20m, Ayozqal'a-1-10-15m, Tashqal'a-2-5m. The state of growth of side wall towers: Kaparas-7 m, Korgoshinkala - 7.6-8 m, Tuprakqala (Khiva) - 5.2 m, Kaparas 27 m, Ayozkala - 1, - 7.5-10 m, Toshkala - 5.5 m, Almaty 2-27 m, Kaparas - 27 m, Ayozkala - 3-27 m. The 
defensive walls of the villages are devoid of towers: Yonboshqal'a, Oqchungul, Ayozqal'a-2. Some settlements do not have wall corner towers (Khiva Soil, Lead).

Gate. Since the gates were a militarily vulnerable area in the defense of rural communities, engineers paid great attention to its defense. The gates were built towards the trade route. The gate served to connect the inner population of the city with the outside world through the corridor. Given the structural structure of the gates, they can be divided into the following types. 1). a labyrinth rebuilt of cotton and a square brick with a one-story corridor covering the area in front of the gate. In terms of structural structure, the labyrinth structure allows it to be divided into two types: Type 1: Labyrinth gates made of single-celled cotton and square bricks, which are fortresses with rectangular and semicircular towers (Ayozqala-1, Pilqal'a, Koyqirqanqala). Type 2: A one-elbow labyrinth in front of the gate, but they are devoid of different types of constellations (Yonboshqal'a, Koyqrilganqala, Kaparas, Ayozqal'a-3). Type 3 . The gate has a semicircular constellation on both sides, but a rectangular and a one-elbow maze in the form of a circle not (Almaty-1, Small and Large Kyrgyzkala, Almaty-2, Oqchakelin, Jildiqqala). Type 4. A one-elbow maze and a ramp gate without towers (Qizilqala). The size of the area of the rectangular misalignment in front of the gate: Koykirilganqala - 0.13 ha, Yonboshqala - 0.1 ha, Korgoshinkala - 0.1 ha, Kaparas - 0.06 ha, Tuprakqala (Khiva) - 0.1 ha.

Shinak. The importance of tires in the defense system is no less than that of towers. From the 5 th century $\mathrm{BC}$ to the 1st century $\mathrm{AD}$, spear-shaped tires were widely used on the outer walls, towers, and frontal labyrinthine walls and towers of rural settlements. The size of the tires was as follows: the distance between the sides $-1.20 \mathrm{~m}$, width $-20 \mathrm{~cm}$, height $-75 \mathrm{~cm}$, and the outside $-2.10 \mathrm{~cm}$, the distance between the tires - 0.9, width - $22 \mathrm{~cm}$, internal height - 0.75, the outside - $2 \mathrm{~m}$ In Ayozkala-1, the distance is $1.5 \mathrm{~m}$, the inside is $13-20 \mathrm{~cm}$, and the outside is $2.9-3.5 \mathrm{~m}$. In some villages, the outer wall and the front of the gate have a labyrinth of many tires (Yonboshqal'a, Koyqrilganqala, Big and Small Qirqqizqala). Some villages did not use tires on the walls and towers (Almaty-2, Tashkhirmontepa).

Ark. By dividing the internal structure of the villages into two parts, the defense complex is of particular importance. The arch is mostly located in the corner of the residence, dividing its interior feature into two parts. It was surrounded by a separate wall and in turn had a gate. Those who have arches: Odoytepa, Ayozqala-3, Dumanqala. Those who do not have an arch: Yonboshqala, Burliqala, Anqaqala, Koyqrilganqala, Small and Big Kyrgyzqala, Ayozqal'a-1, Kaparas, Tiroqqal'a (Yangiariq), Tiroqqal'a (Khiva), Toshqal'a-2, Toqalqala (Qizalqala).

Trench. The trenches were of special importance in the protection of the settlements of the rural communities and were the first line of defense. Archaeological excavations have shown that the settlements, built on the edge of a plateau, at the height of a ridge adjacent to the edge of a ravine, are surrounded on one side by a ditch. Rural settlements on the plain are surrounded by ditches around the square. It is known that the rulers and inhabitants of the ancient Eastern states paid special attention to the construction of cities with a perfect defense system and the development of domestic agricultural oases. [5]

The mud used in the construction of the defensive walls and towers was taken from near it, which led to the formation of wide and deep trenches. The size of the ditches surrounding the settlements: Ayozkala - 3-20 m, depth - $3 \mathrm{~m}$. Yonboshqal'a-20 m, depth $5 \mathrm{~m}$, Tiroqqal'a (Shovot) $-25 \mathrm{~m}$, depth-8 m, Tiroqqal'a (Khiva) $-17 \mathrm{~m}$, depth- $6 \mathrm{~m}$, Almaotishgan-2-3 m, depth-3 $\mathrm{m}$. The ruined fortress is $15 \mathrm{~m}$ deep. [6] The stone-lined ditch surrounding Butentovkala was $2.50 \mathrm{~m}$ deep and $9 \mathrm{~m}$ wide. [7] The trenches allowed the enemy infantry and cavalry to stop and approach the wall, albeit temporarily, allowing the archers standing on the defensive wall and towers to prepare for defensive work. Religious and ideological centers with a defense system: Koykrilqanqala, Tiroqqalqala (Shovot), Chilpiq, Toshqala2.

Military villages: Anqaqal'a, Qizilqal'a, Ayozqal'a-1, Burliqal'a.

The conclusion is that large-scale archeological excavations in the Khorezm oasis and adjacent areas of Sariqamishboy show that from the end of the IX-VIII centuries BC, the settlers learned about clay architecture, first of all, small settlements. The side is surrounded by a cotton-raw brick wall. The fact that the village of Dingilja, built in the Burgutkala oasis on the right bank of the Amu Darya from the second half of the 7th century $\mathrm{BC}$ to the end of the 5th century $\mathrm{BC}$, had a simple defense system indicates the escalation of the military situation. From the 4th century BC to the 1st century AD, under the leadership of a centralized state, the construction of small villages with colorful planning and defense elements took place on a vast plain, in the mountains and at the beginning, middle and end of the main irrigation facilities.

It should be noted that in these historical dates, as the external situation was stable, the construction of housing was a priority in the domestic policy of the centralized state. 

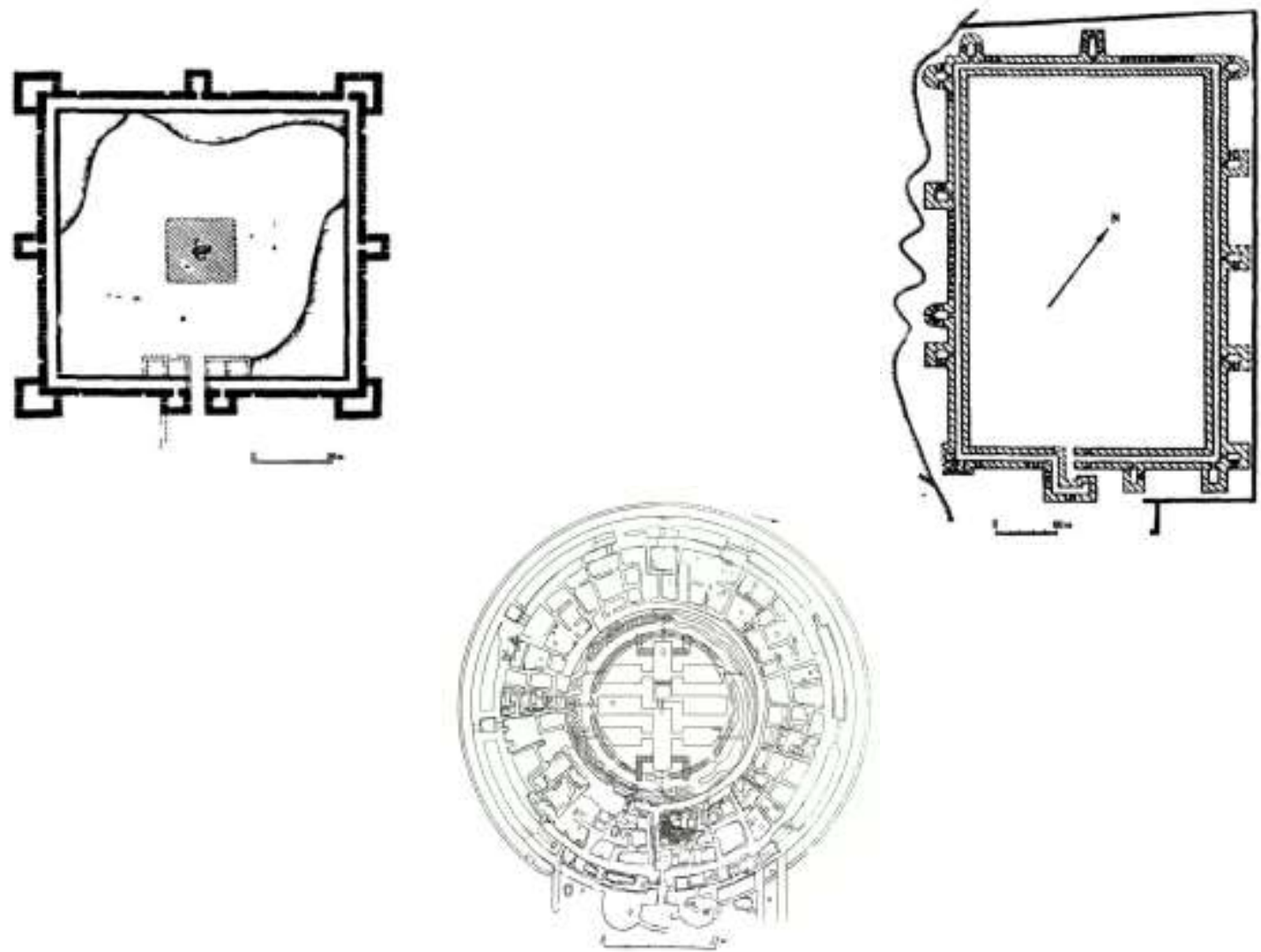

Қўйқирилганқалъа тархи.

(Толстов, 1962, 60-расм)
Анқақалъа тархи.

(Толстов, 1948, 50-расм)

\section{Қўрғошинқалъа}

(Ходжаниязов, 1984)

\section{REFERENCES}

1. Vorob'eva M.G., Lapirov-Skoblo M.S., Nerazik E.E. Archaeological works in Khazoraspe in 1958-1960 gg // MXE // Vyp.6, - M., «Nauka», 1963, - S.190, 194-195.

2. Gertman A.N. Nekotorye osobennosti markkirovki syrtsovyx kirpichey Sredney Azii // Etnografiya i archeologiya Sredney Azii. - M., «Nauka», 1979. - C. 70-73.

3. Mambetullaev M.M. History and culture of Yuzhno Khorezm antichnoy epoxy // IV v do n.e.-IV v n.e.// Author's abstract doc. diss. - Tashkent, 1994, - C. 33.

4. Piotrovskiy B.B., Flitner N.D. Istoriya tehniki drevnego Dvurechya // Essays on istorii tekhnik drevnego Vostoka. -M-L., «Nauka», 1940, - C. 54.

5. Tolstov S.P. In the wake of drevnexorezmiyskoy civilization. - M., «Nauka», 1948, - S.117.

6. Tolstov S.P. Raboty Xorezmskoy archeologo-etnograficheskoy ekspeditsii // AN SSSR v 19491953gg. TXAEE, T.2, - M., «Nauka», 1958, - C. 8.

7. Koy-krylgan-kala - a monument to the culture of ancient Khorezm IV in n.e.-IV in n.e.// TXAEE. T.V, M., «Nauka», 1967, - C. 306.

8. Shperk V.F. History of fortification // Fortification of the ancient world. T.1, - M., «Nauka», 1948, - C. 70. 